\title{
The Effect of Client Importance and Auditor Tenure on Accounting Conservatism: Evidence from Chinese Companies
}

\author{
Bing $\mathrm{Yu}^{1} \&$ Mary Jane Lenard ${ }^{1}$ \\ ${ }^{1}$ School of Business, Meredith College, Raleigh, NC, USA \\ Correspondence: Mary Jane Lenard, School of Business, Meredith College, 3800 Hillsborough Street, Raleigh, \\ NC27607, USA. Tel: 1-919-760-8488. E-mail: lenardmj@meredith.edu
}

Received: November 27, 2012

Accepted: December 6, 2012 Online Published: December 13, 2012

doi:10.5539/ibr.v6n1p176

URL: http://dx.doi.org/10.5539/ibr.v6n1p176

\begin{abstract}
The concern over accounting regulation has resulted in studies of auditor independence and audit quality, as measured by auditor tenure, accounting conservatism, and the type of audit firm the client employs (Big 4 or non-Big 4).In this study, we continue the line of research on conservatism and auditor tenure by examining whether accounting conservatism is related to auditor tenure for Chinese firms. We extend the studies by Jenkins and Velury (2008) and $\mathrm{Li}$ (2010) in order to examine Chinese firms that have non-Big 4 auditors, and we investigate whether the association exists for the most important and least important clients of these audit firms. Our findings indicate that least important clients employ more conservative accounting techniques as auditor tenure increases. For the most important clients, there is less conservatism, compared to the least important clients, in the early years of the auditor's tenure. Our study provides more information about the regulatory issue of mandatory audit firm rotation because our results suggest that mandatory auditor rotation may have an adverse effect on the least important clients of these Chinese audit firms.
\end{abstract}

Keywords: accounting conservatism, auditor tenure, audit quality, earnings quality, Chinese companies

\section{Introduction}

High-profile corporate failures have raised the issue of balancing management's and investors' goal of increased corporate performance with the reliability of companies' financial statements. In a study of U.S. firms, Jenkins and Velury (2008) have noted the general belief that a high quality audit translates to high earnings quality. The authors measured auditor tenure as an indicator of audit quality, combined with a measure of accounting conservatism adapted from models by Basu (1997) and Ball and Shivakumar (2005), as an indicator of earnings quality. The Basu (1997) model measures conservatism by the asymmetric timeliness of reporting bad news relative to good news. By examining this definition of accounting conservatism and its relation to auditor tenure, Jenkins and Velury (2008) documented a positive association between audit quality, as measured by longer auditor tenure, and firms' earnings quality. In contrast, Li (2010) noted that for smaller firms or for firms weakly monitored by their auditors, there was a significantly negative association between auditor tenure and conservatism.

Jenkins and Velury (2008) also addressed the issue of mandatory auditor rotation. Support for this issue is mixed (George, 2004). Previous academic research has found evidence suggesting that mandatory auditor rotation would negatively affect audit quality (Myers et al., 2003; Carcello \& Nagy, 2004). Given their result of a positive association between earnings quality and audit quality as tenure increases, Jenkins and Velury (2008) argued against mandatory auditor rotation as it may have an adverse effect on conservatism in reported earnings.

In this paper we extend the line of research on conservatism and auditor tenure by examining whether accounting conservatism is related to auditor tenure for publicly-traded Chinese firms. As an emerging market, the Chinese stock market is in a high-growth stage. Consequently, investors in the Chinese stock market must rely on reliable and consistent financial statement information to identify good companies in the market. In addition, the majority of investors in the Chinese stock market are individual investors who must use publicly available information disclosed by financial reports (Sutthisit et al., 2012) in order to evaluate their investments. Therefore, it is important to have an effective way to reveal the quality of financial reports in the Chinese stock market. 
In addition to the studies by Jenkins and Velury (2008) and Li (2010) linking auditor tenure and accounting conservatism, additional studies have linked auditor tenure and audit quality, with differing results. Some studies found evidence of lower audit quality in the early years of the auditor-client relationship, with audit quality improving as audit tenure lengthens (Beck \& Soloman, 1988; Geiger \& Raghunandan, 2002; Carcello \& Nagy, 2004; Chi \& Huang, 2004; Boone et al., 2008). Other studies found that audit firm tenure affects audit quality adversely (Hoyle, 1978; Davis et al., 2009; Al-Thuneibat et al., 2011). These studies on audit tenure also contribute to the arguments regarding mandatory auditor rotation and audit independence. Davis et al. (2009) argued in favor of mandatory rotation to provide a "fresh look" at a client's financial statements. Johnson et al. (2002) looked at short (2-3 years), medium (4-8 years), and long (greater than 9 years) audit terms and found that short audit firm tenures are associated with lower-quality financial reports, but that there is no evidence of reduced audit quality for audit tenures of more than eight years.

Li and Wang (2005), in studying companies in the Chinese stock market, found a negative correlation between auditor tenure and non-standard (or modified) audit opinions, reasoning that an auditor with longer tenure would hesitate to issue a non-standard audit report. As such, the authors suggest that longer auditor tenure might impair auditor independence, and they argue in favor of mandatory auditor rotation. Chen and Xia (2006) found that the relationship between auditor tenure and audit quality in China is an inverse " $U$ " shape, referring to their results that audit quality is low in the beginning of the auditor's tenure, then improves up to a certain point in time, then declines again. Both Li and Wang (2005) and Chen and Xia (2006) limited their samples to short time periods (sample span is from 2001 to 2002, and from 2000 to 2002, for Li and Wang (2005), and Chen and Xia (2006), respectively).

In another study of Chinese companies, Navissi et al. (2006) investigated the role of information implied in earnings persistence and components of earnings for stock prices in China. They found that, much as with U.S. firms in U.S. markets, there is a high level of earnings persistence exhibited by Chinese firms that is attributed to the cash flow component of earnings. They also noted that in China, usually larger listed companies are held by a state-owned controlling shareholder, while smaller companies are widely held by numerous smaller investors. Wang and Wong (2003) found that among 1,088 Chinese listed firms in 2001, the average shareholding of state-owned shareholders was $43.1 \%$.

In addition, the structure of the standards for auditing and reporting in China is relatively new compared to the U.S. markets. In China, for many years accounting firms and auditing firms were separate entities (Doupnik \& Perera, 2009). During the process of standardizing their different rules, many of these accounting and auditing firms came together as affiliates of a sponsoring organization, usually a government agency, in order to report the financial information of companies listed on the stock markets. This arrangement may limit an auditing firm's independence, as the auditor may feel obligated to report the financial results in a particular way that favors the sponsoring organization. Further, it is a common practice in Chinese culture for a close association to exist between companies that do business together (Doupnik \& Perera, 2009). Both of these practices have the potential to influence the ethics-related considerations that may face auditors in reporting client performance (Seligman, 1999; Dai et al., 2000; Islamand \& Gowing, 2003). Due to these differences in business association and ownership structure, larger and smaller firms have different earnings management behaviors (Noronha, 2008). We would expect to see Chinese firms with different sizes exhibit accounting conservatism differently in order to make their company's earnings, and therefore their stock price, less volatile and more attractive to investors. We would then also expect the firms to seek a measure of high audit quality in order to further enhance their company's reputation. Accordingly, we examine auditor tenure as a means to observing the Chinese firms' audit quality.

The purpose of this paper is to explore the relationship between auditor tenure and financial reporting quality of Chinese firms. To implement our study, we use a sample of Chinese firms from 1997 through 2007. We divide our sample into quartile sub-groups based on client importance of auditors so as to check different sizes of firms separately. We use the models from the Jenkins and Velury (2008) study (both the Basu (1997) model and the Ball and Shivakumar (2005) model) and the $\mathrm{Li}$ (2010) study to measure earnings conservatism and the relationship between auditor tenure and conservatism.

The results obtained in this paper are expected to extend the research in studies of audit quality and financial statement conservatism in the Chinese stock market. The empirical findings of this study shed light on the association between auditor tenure and accounting conservatism for Chinese firms and observe a time frame for the auditor-client relationship that indicates when financial statement quality for those firms is most prevalent. This study provides further evidence of audit quality that is useful to investors and regulators in the Chinese stock market. 
The remainder of this paper is organized as follows. Section 2 provides background and literature review. Section 3 describes the sample and methodology. Section 4 presents the results, and Section 5 concludes the paper.

\section{Theoretical Background}

\subsection{Information Contained in Stock Prices and Reported Earnings}

Sloan (1996) has investigated whether stock prices reflect information about future earnings that is contained in the accrual and cash flow components of current earnings. The extent to which current earnings performance persists into the future was found to depend on the relative magnitudes of the cash and accrual components of current earnings, although stock prices act as if investors fail to identify correctly the different properties of the two components of earnings. Richardson et al. (2005) extended the work and found that less reliable accruals lead to lower earnings persistence. Navissi et al. (2006) used the earnings persistence model to study Chinese firms, and found that while there was a high level of earnings persistence in the sample firms, which was attributed to the cash flow rather than the accrual component of earnings, the investors in China failed to anticipate the information contained in earnings persistence. Furthermore, they under-priced both the cash flow and accrual components of earnings (Navissi et al., 2006). As a result, Chinese investors could benefit from accurate information contained in earnings.

Through voluntary disclosure practices, firms can encourage investment and manage the risk borne by investors. Firms can reduce information risk by employing conditional accounting conservatism, which involves the timely recognition of economic losses and thereby improves contracting efficiency (Ball \& Shivakumar, 2005). Basu (1997) measures conservatism by the asymmetric timeliness of reporting bad news relative to good news. The model is based on the premise that stock prices reflect information from sources other than financial statements and that stock prices lead earnings information (Jenkins \& Velury, 2008).

\subsection{Reported Earnings and Measures of Audit Quality}

In the U.S., the Sarbanes-Oxley act (SOX) was passed in 2002 in response to a series of financial reporting failures in 2001-2002.A large part of the SOX legislation deals with rules regarding auditor independence and audit quality. The SOX legislation is also meant to improve corporate governance, by including the section of the law on corporate responsibility (US Congress, 2002, p. 31). Chinese firms are also striving to improve their corporate governance. In a research study that explored earnings management in China, Noronha et al. (2008) noted that a sound framework of corporate governance has become a top priority in the Chinese government's agenda. Thus, an impetus for improved corporate governance can encourage the demand for higher quality audits and improve financial reporting quality in China, as the SOX legislation is meant to do in the United States.

$\mathrm{Li}$ (2010) has noted a number of proxies for the presence (or absence) of audit quality. These proxies include discretionary accruals, the cost of debt financing, the failure to issue going-concern audit reports before bankruptcy filings, and financial reporting fraud. Geiger and Raghunandan (2002) have suggested that auditors are less likely to modify opinions for financial statements immediately preceding bankruptcy if they are in the initial years of engagement with a client. Carcello and Nagy (2004) found that fraudulent reporting is more likely to occur in the early years of the auditor-client relationship. Beck and Solomon (1988) observed a lower likelihood of detecting misstatements in the early years of the audit-client relationship. Boone et al. (2008) have argued that client-specific knowledge is crucial to building a sufficient level of familiarity with the client's accounting system. Similarly, Chi and Huang (2004) observed a "learning effect" and reported that the ability to investigate accounting irregularities is a function of audit tenure. Myers et al. (2003) found that auditor tenure is positively related to earnings quality using discretionary accruals as a proxy for earnings quality. These findings suggest that financial reporting quality and audit quality would increase as the length of the auditor-client relationship increases.

Yet Davis et al. (2009) found that firms with long tenure (13-15 years or more) are more likely to report levels of discretionary accruals that allow them to meet or beat earnings forecasts. They also found the same for firms with short tenure of two or three years. Hoyle (1978) found that an auditor with long tenure had less objective behavior. Al-Thuneibat et al. (2011) studied firms in Jordan and found that audit firm tenure affected audit quality adversely. Li (2010) extended the study by Jenkins and Velury (2008) and found a positive association between accounting conservatism in reported earnings and auditor tenure, although it was true only for large firms - for smaller firms or firms that were weakly monitored by their auditors, Li (2010) observed a significantly negative association between auditor tenure and conservatism. Li's (2010) findings are corroborated by the accruals-based models of Givoly and Hayn (2000) and Ahmed et al (2002).Using these models, Li (2010) found that as audit tenure increases, aggregate accruals increase for less important clients and decrease for more 
important clients.

Therefore, in order for Chinese companies to exhibit improved earnings quality and draw investors to their stocks, they too will need to show improved audit quality. Exhibiting audit quality through the use of accounting conservatism would be one way to accomplish this goal. Using the model developed by Jenkins and Velury (2008), and based on Basu (1997), we propose to measure the earnings quality of the Chinese firms in our sample. We first measure the effect of accounting conservatism on client earnings. This leads to our first hypothesis:

\section{H1: Accounting conservatism is positively related to earnings for all audit clients}

The premise of this hypothesis is that by practicing accounting conservatism in the timely reporting of bad news, stock returns will be positive, which will then result in positive earnings as well. Jenkins and Velury (2008) then went on to relate auditor tenure to accounting conservatism by measuring the interaction of tenure with the speed of good news, and bad news, recognition. They found that earnings conservatism increased, for all clients, with longer auditor tenure. However, Li (2010) found that this relationship existed only for larger clients of audit firms. On the other hand, Carcello and Nagy (2004) noted that larger clients have greater bargaining power and are more likely to convince the auditor to allow more aggressive accounting. For our study, we use audit tenure as a proxy for audit quality. Further, we examine whether client factors affect the audit quality by testing specific groups ranked by client importance, as measured by client size. We then propose our second hypothesis:

H2: Longer auditor tenure and accounting conservatism are positively related to earnings for all audit clients

\section{Methodology}

\subsection{Sample Selection}

We obtained a sample of Chinese firms from 1997 through 2007, retrieved from the Compustat Global database. The Chinese stock market was established in December 1990. As a result, there was a very limited number of firms listed on the stock market in the first few years. For example, 6, 24, and 77 firms were listed on the Shanghai stock exchange in 1991, 1992, and 1993, respectively. Before 1997, the Chinese stock market experienced frequent regulation and de-regulation switches. Therefore, in order to provide a consistent regulatory environment for the firms in our study, we build our sample starting with 1997.

Unlike the U.S. stock market, in which the majority of listed firms hire Big 4 auditors, Chinese companies do not necessarily hire Big 4 auditors. Most of them hire local audit firms. Therefore, as the availability of clients with Big 4 auditors was limited (only 80 of the Chinese firms listed on the database had Big 4 auditors for the time period of our study), we examine the audit quality of non-Big 4 auditors. The initial number of firms in our study is 1,201 .

Our sample spans an 11-year time period. We include firm-year observations in our sample only for those companies whose variables of earnings, auditor, and stock returns are available in the Compustat database. We collected stock prices and number of shares outstanding information from the Compustat Global Security Daily database. All accounting variables and auditor data are collected from the Compustat Global Fundamentals Annual database. Our sample includes A-share companies listed in Shanghai or Shenzhen stock exchanges. We exclude dual-class firms because B-class shares are denominated by foreign currencies, either in U.S. Dollars or Hong Kong Dollars, and are subject to the application of multiple accounting principles. Consistent with the literature, we exclude financial services industry firms (SIC code between 6000 and 6999) because of special auditing regulations in that industry. Our remaining sample consists of 3,854 firm-year observations. To control for the effect of outliers, we Winsorize all study variables from top and bottom at the $1 \%$ level.

We use the models proposed by Jenkins and Velury (2008), and the further measures of client importance used by $\mathrm{Li}$ (2010) to examine whether auditor tenure and the importance of the client influence the extent of accounting conservatism employed by the auditor and the client. We would expect firms that are more closely monitored to reflect more conservatism in their accounting practices. Auditor tenure is measured by the number of years the firm has retained the same auditor. We define client importance using a method similar to Li (2010), in that client importance is measured as the client's sales as a proportion of total sales, within the particular 2-digit SIC code. We then divide the sample into quartiles based on client importance as a proxy for the strength of outside monitoring. For brevity, we present the results only for the contrast in the least important (bottom quartile) and most important (top quartile) groups.

\subsection{Regression Models}

Consistent with the Jenkins and Velury (2008) and Li (2010), the first model that we employ is based on the 
model by Basu (1997) and measures the effect of earnings conservatism without regard to auditor tenure:

$$
E A R N_{i t}=\beta_{0}+\beta_{1} R E T_{i t}+\beta_{2} D R E T_{i t}+\beta_{3} R E T_{i t} * D R E T_{i t}+\varepsilon_{i t}
$$

where for firm $i$ in year $t$ : EARN is earnings before extraordinary items deflated by market value of equity at the beginning of the period; RET is the fiscal year stock return; and DRET is the dichotomous variable set to one if RET $<0$, zero otherwise. The premise in this model is that stock prices reflect information from sources other than financial statements (Ball \& Brown, 1968). The coefficient $\beta_{1}$ captures the response of earnings to returns when returns are positive. A positive coefficient $\beta_{1}$ thus indicates that returns are positively related to earnings. The coefficient $\beta_{1}$, along with coefficient $\beta_{3}$ of the interaction term, measures the response of earnings to returns when returns are negative. If $\beta_{3}>0$, or if $\beta_{1}+\beta_{3}>\beta_{1}$, it is an indication that earnings reflect bad news more quickly than good news, meaning earnings are conservatively reported, and accounting conservatism is positively related to earnings.

The second model includes the effect of auditor tenure on conservatism:

$$
\begin{aligned}
& E A R N_{i t}=\beta_{0}+\beta_{1} R E T_{i t}+\beta_{2} D R E T_{i t}+\beta_{3} R E T_{i t} * D R E T_{i t}+\beta_{4} T E N U R E_{i t}+ \\
& \beta_{5} \text { TENURE }_{i t} * R E T_{i t}+\beta_{6} \text { TENURE }_{i t} * D R E T_{i t}+\beta_{7} \text { TENURE }_{i t} * R E T_{i t} * D R E T_{i t}+\varepsilon_{i t}
\end{aligned}
$$

In this model, TENURE is the number of years the firm has retained the same auditor and all other variables are as defined above. The coefficient $\beta_{5}$ of the interaction term between TENURE and RET measures the incremental effect of tenure on the speed of good news recognition, and $\beta_{5}+\beta_{7}$ measures the impact of tenure on the speed of bad news recognition. A positive and significant coefficient $\beta_{7}$ would indicate that earnings conservatism is increasing with longer auditor tenure.

\section{Results}

Table 1 shows descriptive statistics of the variables. Panel A is the pooled sample of all firms with non-Big 4 auditors, Panel B represents the least important clients group, and Panel $\mathrm{C}$ represents the most important clients group. The mean value of TENURE of the pooled sample is 8.178 years, and the mean of the least important and most important groups is similar to that. The mean of the return variable RET (fiscal year stock return) is 0.533 for the least important firms, the mean return (RET) is 0.717 , significantly higher than the mean return (RET) of 0.430 for the most important firms. The mean earnings (EARN)are 0.022 for the pooled sample, which is slightly higher than the mean earnings reported by Jenkins and Velury (2008) and Li (2010), who reported mean earnings of 0.013 and 0.011 , respectively. Mean earnings are negative for least important firms (-0.027), and positive for most important firms $(0.043)$ in our sample. There is a much wider variation in earnings for the least important clients, from a minimum of -3.196 to a maximum of 2.241, compared to a minimum of -1.555 and a maximum of 1.188 for the most important clients. The variable DRET is the dichotomous variable set to 1 if the return is less than 0 . The statistics for DRET show that the proportion of observations with negative returns for the pooled sample is 0.401 . This compares to a proportion of 0.472 for Jenkins and Velury (2008) and a proportion of 0.569 for $\mathrm{Li}$ (2010). The proportion of negative returns for the least important group in our sample is 0.294 ; for the most important clients, the proportion of negative returns is 0.459 .

\begin{tabular}{|c|c|c|c|c|c|}
\hline & TENURE & RET & EARN & DRET & $\mathrm{ACC}$ \\
\hline Mean & 8.178 & .5329 & .0228 & .4014 & -.040 \\
\hline Median & 10 & .1573 & .0313 & 0 & -.031 \\
\hline SD & 3.295 & 1.067 & .1448 & .4902 & .104 \\
\hline Minimum & 1 & -.9093 & -3.196 & 0 & -.608 \\
\hline Maximum & 12 & 8.499 & 2.241 & 1 & .206 \\
\hline T-value & $3.800 * * *$ & $6.144 * * *$ & $-14.392 * * *$ & $-7.208 * * *$ & $-3.994 * * *$ \\
\hline \multicolumn{6}{|l|}{$\mathrm{N}=3854$} \\
\hline \multicolumn{6}{|c|}{ Panel B The least important clients group } \\
\hline & TENURE & RET & EARN & DRET & $\mathrm{ACC}$ \\
\hline Mean & 7.972 & .7165 & -.0269 & .2938 & -.063 \\
\hline Median & 10 & .3539 & .0158 & 0 & -.024 \\
\hline SD & 3.324 & 1.169 & .2529 & .4559 & .168 \\
\hline Minimum & 1 & -.7609 & -3.196 & 0 & -.606 \\
\hline Maximum & 12 & 8.34 & 2.241 & 1 & .205 \\
\hline
\end{tabular}

Table 1. Descriptive Statistics

Panel A Pooled sample 
Panel C The most important clients group

\begin{tabular}{|c|c|c|c|c|c|}
\hline & TENURE & RET & EARN & DRET & $\mathrm{ACC}$ \\
\hline Mean & 7.820 & .4302 & .0498 & .4586 & -.041 \\
\hline Median & 10 & .0566 & .0474 & 0 & -.039 \\
\hline SD & 3.535 & 1.051 & .1142 & .4985 & .079 \\
\hline Minimum & 1 & -.8844 & -1.555 & 0 & -.608 \\
\hline Maximum & 12 & 6.853 & 1.188 & 1 & .206 \\
\hline
\end{tabular}

$\mathrm{N}=1354$

Note: $\mathrm{N}=$ number of firm-year observations; TENURE $=$ the number of years since the auditor has been employed; RET= stock return of fiscal year; EARN= earnings before extraordinary items at the fiscal year-end divided by the market value of equity at the beginning of fiscal year; DRET= a dummy variable that is equal to 1 if RET is negative, and zero otherwise. ACC is the accruals, calculated as the difference between earnings before extraordinary items and cash flow from operations, deflated by total assets, then averaged over a 3 -year period centered on year t. Client importance is measured by the portion of a client's sales in the total sales of the two-digit SIC code industry segment. Sample firms are divided into quintiles. The least important clients group is the bottom group in which firms' client importance is less than 0.0000572 while the most important clients group is the top group in which firms' client importance is greater than 0.0004475 . $\mathrm{T}$-value is the result of t-test comparison between the least important and the most important client groups. *** denotes $1 \%$ significance level.

We also computed the accruals (ACC) for the sample, calculated as the difference between earnings before extraordinary items and cash flow from operations, deflated by total assets, then averaged over a 3-year period centered on year $t$. We compared the accruals for the client groups, and found that the least important client group had significantly lower accruals (mean of -0.063) than the most important client group (mean of -0.041).

The results of model (1) for the complete (pooled) sample, and the client groups, are shown in Table 2. The results show that all variables in model (1) are significant for the pooled sample. Coefficient $\beta_{3}$ of the RET*DRET variable is positive and significant for the pooled sample and the client groups, which means that bad news is reported more quickly than good news. This supports H1, that accounting conservatism is positively related to earnings for these Chinese companies.

Table 2. Regression analysis results

\begin{tabular}{llll}
\hline & Model $(1)$ & $\begin{array}{l}\text { The Least Important } \\
\text { Clients Group }\end{array}$ & $\begin{array}{l}\text { The Most Important } \\
\text { Clients Group }\end{array}$ \\
\hline Dependent Variable & EARN & EARN & EARN \\
\hline RET & $0.016^{* * *}$ & $0.019^{* * *}$ & $0.021^{* * *}$ \\
DRET & $(0.002)$ & $(0.008)$ & $(0.002)$ \\
& $0.008^{*}$ & 0.017 & 0.000 \\
RET*DRET & $(0.004)$ & $(0.016)$ & $(0.006)$ \\
& $0.061^{* * *}$ & $0.164^{* * *}$ & $0.038^{* * *}$ \\
Constant & $(0.013)$ & $(0.047)$ & $(0.019)$ \\
& & & \\
Observations & $0.017^{* * *}$ & $-0.026^{* * *}$ & $0.047^{* * *}$ \\
Adj-R square & $(0.003)$ & $(0.087)$ & $(0.004)$ \\
\hline
\end{tabular}

Note: Standard errors in parentheses; $*$ significant at $10 \% ; * *$ significant at $5 \% ; * * *$ significant at $1 \%$.

Description: Table 2 presents the regression results of Model (1): $\mathrm{EARN}_{i t}=\beta_{0}+\beta_{1} \mathrm{RET}_{i t}+\beta_{2} \mathrm{DRET}_{i t}+\beta_{3} \mathrm{RET}_{i t} * \mathrm{DRET}_{i t}+\varepsilon_{i t}, \mathrm{where}_{\mathrm{for}}$ firm $i$ in year $t$ : EARN is earnings before extraordinary items deflated by market value of equity at the beginning of the period; RET is the fiscal year stock return; DRET is the dichotomous variable set to 1 if RET $<0$, zero otherwise.

In order to further investigate these findings, Table 3 shows the results, using Model (2), for the least important and most important client groups. Panel A shows that the coefficient $\beta_{7}$ of the TENURE*RET*DRET variable is positive and significant only for the least important clients. This indicates that the speed of recognition of bad news occurs with longer audit tenure. For the most important clients, the coefficient $\beta_{7}$ is negative and not significant. The coefficient of the interaction term, $\beta_{3}$, is positive and significant, which means the companies display accounting conservatism in terms of the speed of reporting bad news, but the speed of reporting does not increase as audit tenure increases. Thus, $\mathrm{H} 2$ is supported for the least important clients, in that longer audit tenure and accounting conservatism are positively related to earnings. However, $\mathrm{H} 2$ is not supported for the most 
important client group.

Table 3. Regressions analysis results for least and most important client groups

\begin{tabular}{lll}
\hline & The least important clients group & The most important clients group \\
\hline Dependent Variable & EARN & EARN \\
\hline RET & $0.036^{* *}$ & $0.039^{* * *}$ \\
DRET & $(0.018)$ & $(0.007)$ \\
& -0.000 & $0.054^{* * *}$ \\
RET*DRET & $(0.043)$ & $(0.017)$ \\
& -0.072 & $0.095^{* *}$ \\
TENURE & $(0.112)$ & $(0.046)$ \\
& 0.002 & $0.004^{* * *}$ \\
TENURE*RET & $(0.003)$ & $(0.001)$ \\
& -0.002 & $-0.002^{* * *}$ \\
TENURE*DRET & $(0.002)$ & $(0.001)$ \\
& 0.003 & $-0.007 * *$ \\
TENURE*RET*DRET & $(0.005)$ & $(0.002)$ \\
& $0.031^{* *}$ & -0.007 \\
Constant & $(0.013)$ & $(0.005)$ \\
Observations & $-0.044^{*}$ & 0.012 \\
Adj-R square & $(0.024)$ & $(0.011)$ \\
\hline
\end{tabular}

Note: Standard errors in parentheses; *significant at $10 \%$; ** significant at $5 \%$; *** significant at $1 \%$.

Description: Table 3 presents the regression results of Model (2): EARN ${ }_{i t}=\beta_{0}+\beta_{1} \mathrm{RET}_{i t}+\beta_{2} \mathrm{DRET}_{i t}+\beta_{3} \mathrm{RET}_{i t} * \mathrm{DRET}_{i t}+\beta_{4} \mathrm{TENURE}_{i t}+$ $\beta_{5} \mathrm{TENURE}_{i t} * \mathrm{RET}_{i t}+\beta_{6} \mathrm{TENURE}_{i t} * \mathrm{DRET}_{i t}+\beta_{7} \mathrm{TENURE}_{i t} * \mathrm{RET}_{i t} * \mathrm{DRET}_{i t}+\varepsilon_{i t}$, where for firm $i$ in year $t$ : EARN is earnings before extraordinary items deflated by market value of equity at the beginning of the period; RET is the fiscal year stock return; DRET is the dichotomous variable set to 1 if RET $<0$, zero otherwise; TENURE is the number of years the auditor hasbeen employed.

\subsection{Additional Testing}

\subsubsection{Accrual-based Measure of Conservatism}

We then perform additional testing on our sample using an accrual-based measure of conservatism. Table 4 shows the results of a model adapted from a model proposed by Li (2010), Givoly and Hayn (2000), and Ahmed et al. (2002). This accrual-based proxy for conservatism is based on the theory that conservative accounting results in persistently negative accruals. The more negative the average accruals over the respective time periods, the more conservative the accounting. The model is as follows:

$$
\begin{aligned}
A C C_{i t}= & \beta_{0}+\beta_{1} T_{E N U R E_{i t}}+\beta_{2} \text { SIZE }_{i t}+\beta_{3} \text { CFO }_{i t}+\beta_{4} S A L E S G R O W T H_{i t} \\
& +\beta_{5} L E V E R A G E_{i t}+\beta_{6} C A P X_{i t}+\varepsilon_{i t},
\end{aligned}
$$

where for firm $i$ in year $t$ : ACC is the accruals, calculated as the difference between earnings before extraordinary items and cash flow from operations, deflated by total assets, then averaged over a 3-year period centered on year $t$; SIZE is the natural log of total assets; CFO is the cash flow from operations deflated by total assets; TENURE is the number of years since the auditor has been hired; SALESGROWTH is the annual growth rate of total sales; LEVERAGE is the total long-term liability deflated by total assets; CAPX is capital expenditure deflated by net property, plant and equipment; and AGE is the number of years since the firm is included in Compustat database. Ahmed et al (2002) and Li (2010) used research and development expenditures to measure increased investment. However, Adam and Goyal (2008) discussed alternative measures of investment opportunity and have suggested that CAPX is also a good proxy for investment opportunity. We chose to use the CAPX ratio because research and development costs were not separately listed for the Chinese companies in the database.

This model reflects the dual role for the relationship between accruals and cash flows. Dechow et al. (1998) note that a negative relationship between accruals and cash flows reflects that the noise, or volatility, in cash flows can be mitigated with accruals. The results of this model for our sample (shown in Table 4) indicate that for both the least important and most important clients, there is a significant and negative relationship between cash flows (CFO) and accruals. The results also show that auditor tenure is not related to higher accruals for the least 
important clients, as the TENURE variable is not significant. This result is similar to the findings of our previous models. However, the model does indicate that auditor tenure is significantly and positively related to higher accruals for the most important clients group, which reflects less conservative accounting. This finding is in contrast to the findings by $\mathrm{Li}$ (2010), whose study indicated the opposite result for the less important and more important client groups.

Table 4. Accrual-based measure of conservatism

\begin{tabular}{llll}
\hline & The Least important clients & The Most important clients & Pooled sample \\
\hline Dependent variable & ACC & ACC & ACC \\
\hline TENURE & -0.001 & $0.002^{*}$ & -0.000 \\
& $(0.003)$ & $(0.001)$ & $(0.001)$ \\
SIZE & 0.009 & $0.010^{* * *}$ & $0.016^{* * *}$ \\
& $(0.010)$ & $(0.003)$ & $(0.002)$ \\
CFO & $-0.495^{* * *}$ & $-0.766^{* * *}$ & $-0.736^{* * *}$ \\
& $(0.117)$ & $(0.028)$ & $(0.024)$ \\
SALESGROWTH & $0.011^{* * *}$ & $0.016^{* * *}$ & $0.011^{* * *}$ \\
& $(0.004)$ & $(0.004)$ & $(0.002)$ \\
LEVERAGE & 0.033 & $-0.052^{* *}$ & $-0.041^{* *}$ \\
& $(0.073)$ & $(0.024)$ & $(0.021)$ \\
CAPX & -0.000 & $0.046^{* * *}$ & 0.000 \\
& $(0.000)$ & $(0.012)$ & $(0.000)$ \\
AGE & $-0.022^{* * *}$ & $-0.003 * *$ & $-0.003^{* * *}$ \\
& $(0.008)$ & $(0.001)$ & $(0.001)$ \\
Constant & -0.023 & $-0.077^{* *}$ & $-0.104^{* * *}$ \\
Observations & $(0.074)$ & $(0.031)$ & $(0.017)$ \\
Adj-R square & 582 & 1354 & 3854 \\
\hline
\end{tabular}

Note: Standard errors in parentheses; $*$ significant at $10 \% ; * *$ significant at $5 \% ; * * *$ significant at $1 \%$.

Description: In Table 4, ACC is accruals, calculated as the difference between earnings before extraordinary items and cash flow from operations, deflated by total assets, then averaged over a 3-year period centered on year $t$; SIZE is the natural log of total assets; CFO is the cash flow from operations deflated by total assets; TENURE is the number of years the auditor has been employed; SALESGROWTH is the annual growth rate of total sales;LEVERAGE is the total long-term liability deflated by total assets; CAPX is capital expenditure deflated by net property, plant and equipment; AGE is the number of years that the firm is included in the Compustat database.

\subsubsection{Skewness of Earnings}

Li (2010) and Givoly and Hayn (2000) noted that if, as we have described, conservative reporting means the early and full recognition of unfavorable events, then the earnings distribution would be negatively skewed. In contrast, if the earnings distribution exhibited a decreasingly negative skewness as auditor tenure increased, it would indicate less conservatism. Following Li (2010), and shown in Figure 1, we compute ROA as the ratio of net income to total assets, and skewness is defined as $\mathrm{y}=E(x-\mu)^{3} / \sigma^{3}$ where $\mu$ and $\sigma$ are the mean and standard deviation of the $x$ distribution. The auditor tenure range in our sample is between 1 and 12, as indicated in Table 1.In this range, as auditor tenure increases, the earnings distribution for the most important clients in our sample becomes decreasingly negative skewed, especially in the early years of the auditor's tenure. In contrast, the graph for the least important clients does not show this trend, as the skewness of earnings remains negative for this group, particularly after a mid-range tenure of five years. This is in contrast to the behavior reflected by the less important companies in Li's (2010) study, which showed a sharp positive increase in year 4. The average skewness for the least important group in our sample is -0.145 , while the average skewness for the group of most important clients is 0.022 .

Taken together, using the above conservatism measures, our findings demonstrate that there is an association between auditor tenure and conservatism for these Chinese companies, and the association varies depending on client importance. For the least important clients, accounting conservatism, as measured by the speed of reporting bad news in relation to good news, increases as audit tenure increases. For the most important clients, accruals increase with audit tenure, and earnings as measured by ROA exhibit a decreasingly negative skewness as auditor tenure increases. 


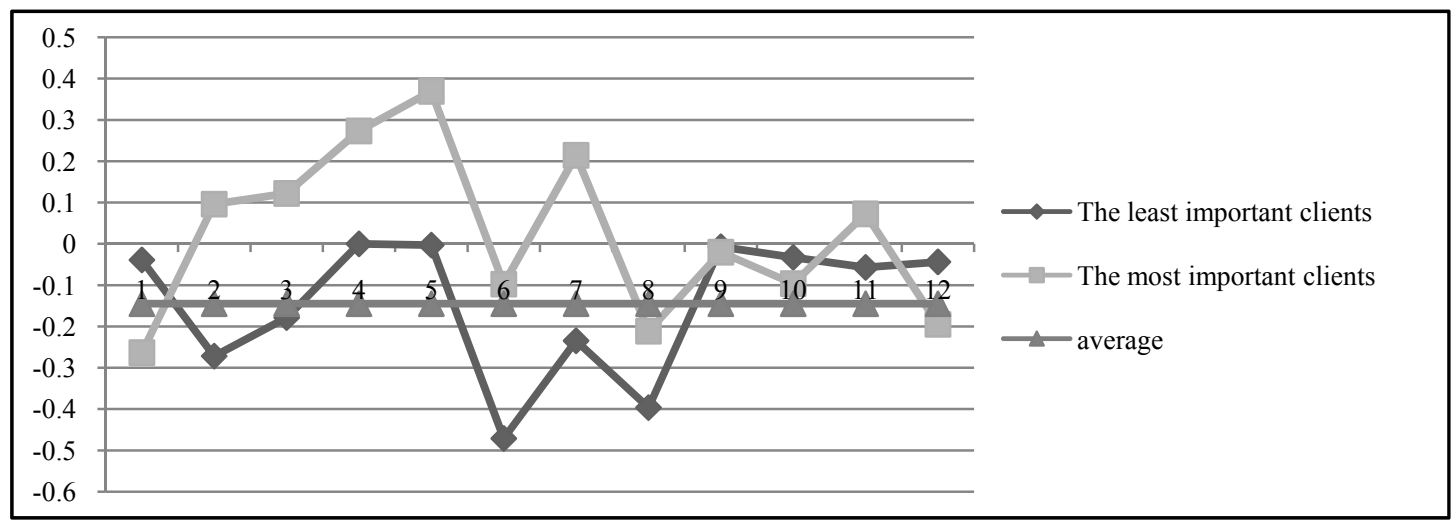

Figure 1. Skewness of ROA vs. TENURE for the least important and most important client groups

Description: Skewness measure of earning distributions as auditor tenure changes by different groups. ROA is the ratio of net income to total assets, and skewness is defined as $\mathrm{y}=E(x-\mu)^{3} / \sigma^{3}$ where $\mu$ and $\sigma$ are the mean and standard deviation of the $x$ distribution. TENURE is the number of years since the auditor has been employed. AVERAGE is the average skewness of the least important group. The average skewness for the least important group is -0.145 . The average skewness for the most important group is 0.022 .

\section{Conclusions}

Our study continues the examination of the relationship between auditor tenure and audit quality that has been the subject of regulatory intervention and studied by previous authors. In our study of publicly-traded Chinese companies, we employed models to evaluate the relationship between client importance and auditor tenure, as proxies for audit quality, and accounting conservatism. We applied these measurements for companies in our sample that employed non-Big 4 auditors. The least important clients in our sample behaved more like the more important clients of Big 4 companies studied by Li (2010).Specifically, companies in the least important audit client group employed more accounting conservatism as auditor tenure increased. On the other hand, accounting conservatism in terms of the speed of reporting bad news did not increase with auditor tenure for the most important clients. In terms of the issue of mandated auditor rotation, the results from our sample indicate that mandatory auditor rotation would not be indicated for least important clients, as conservatism increases with auditor tenure. However, as the accruals increase with auditor tenure for the most important clients, this may indicate that in order to keep a client that is a significant part of their business, the auditor does not object to the client's less conservative reporting methods. Future research could clarify these issues as more Chinese firms are listed publicly, and as the Chinese stock market matures.

\section{References}

Adam, T., \& Goyal, V. K. (2008). The investment opportunity set and its proxy variables. Journal of Financial Research, 31(1), 41-63. http://dx.doi.org/10.1111/j.1475-6803.2008.00231.x

Ahmed, A. S., Billings, B. K., Morton, R. M., \& Stanford-Harris, M. (2002). The role of accounting conservatism in mitigating bondholder-shareholder conflicts over dividend policy and in reducing debt costs. The Accounting Review, 77(4), 867-890. http://dx.doi.org/10.2308/accr.2002.77.4.867

Al-Thuneibat, A. A., Ibrahim Al Issa, R. T., \& Ata Baker, R. A. (2011). Do audit tenure and firm size contribute to audit quality? Managerial Auditing Journal, 26(4), 317-334. http://dx.doi.org/10.1108/02686901111124648

Ball, R., \& Brown, P. (1968). An empirical evaluation of accounting income numbers. Journal of Accounting Research, 6(2), 159-178. http://dx.doi.org/10.2307/2490232

Ball, R., \& Shivakumar, L. (2005). Earnings quality in UK private firms: Comparative loss recognition timeliness. Journal of Accounting Research, 44(2), 207-242. http://dx.doi.org/10.1111/j.1475-679X.2006.00198.x

Basu, S. (1997). The conservatism principle and the asymmetric timeliness of earnings. Journal of Accounting and Economics, 24(1), 3-37. http://dx.doi.org/10.1016/S0165-4101(97)00014-1

Beck, P., \& Solomon, I. (1988). A model of the market for MAS and audit services: Knowledge spillovers and auditor-auditee bonding. Journal of Accounting Literature, 1, 50-64.

Boone, J., Khurana, I., \& Raman, K. (2008). Audit tenure and the equity risk premium. Journal of Accounting, 
Auditing, and Finance, 23(1), 115-140.

Carcello, J., \& Nagy, A. (2004). Audit firm tenure and fraudulent financial reporting. Auditing: A Journal of Practice and Theory, 23(2), 55-69. http://dx.doi.org/10.2308/aud.2004.23.2.55

Chen, X., \& Xia, L. (2006). Auditor tenure and audit quality: Empirical evidence from Chinese securities market. Accounting Research, (in Chinese) 1, 1.

Chi, W., \& Huang, H. (2004). Discretionary accruals, audit-firm tenure and audit-partner tenure: Empirical evidence from Taiwan. Working paper, National Chengchi University, Taipei.

Dai, X., Lav, A., \& Yang, J. (2000). Hooking-up: A unique feature of China's public accounting firms. Managerial Finance, 26(5), 21-30. http://dx.doi.org/10.1108/03074350010766657

Davis, R. L., Soo, B. S., \& Trompeter, G. M. (2009). Auditor tenure and the ability to meet or beat earnings forecasts. Contemporary Accounting Research, 26(2), 517-548. http://dx.doi.org/10.1506/car.26.2.8

Dechow, P., Kothari, S. P., \& Watts, R. L. (1998). The relation between earnings and cash flows. Journal of Accounting and Economics, 25, 133-168. http://dx.doi.org/10.1016/S0165-4101(98)00020-2

Doupnik, T., \& Perera, H. (2009). International Accounting (2nd ed.). New York: McGraw-Hill / Irwin.

Easterbrook, F. (1984). Two agency cost explanations of dividends. American Economic Review, 74, $605-659$.

Geiger, M. A., \& Raghunandan, K. (2002). Auditor tenure and audit reporting failures. Auditing: A Journal of Practice and Theory, 21(1), 67-78. http://dx.doi.org/10.2308/aud.2002.21.1.67

George, N. (2004). Auditor rotation and the quality of audits. The CPA Journal, 74(12), 22-26.

Givoly, D., \& Hayn, C. (2000). The changing time series properties of earnings, cash flows and accruals: Has financial reporting become more conservative? Journal of Accounting and Economics, 29(3), 287-320. http://dx.doi.org/10.1016/S0165-4101(00)00024-0

Hoyle, J. (1978). Mandatory auditor rotation: the arguments and an alternative. Journal of Accountancy, 145(5), 69-78.

Islamand, M., \& Gowing, M. (2003). Some empirical evidence of Chinese accounting system and business management practices from an ethical perspective. Journal of Business Ethics, 42(4), 358.

Jenkins, D. S., \& Velury, U. (2008). Does auditor tenure influence the reporting of conservative earnings? Journal of Accounting and Public Policy, $115-132$. http://dx.doi.org/10.1016/j.jaccpubpol.2008.01.005

Johnson, V. E., Khurana, I. K., \& Reynolds, J. K. (2002). Audit-firm tenure and the quality of financial reporting. Contemporary Accounting Research, $\quad$ 19(4), http://dx.doi.org/10.1506/LLTH-JXQV-8CEW-8MXD

Li, B., \& Wang, P. (2005). The empirical research on auditor independence and mandatory auditor rotation. Journal of Modern Accounting and Auditing, 1(5), 72-80.

Li, D. (2010). Does auditor tenure affect accounting conservatism? Further evidence. Journal of Accounting and Public Policy, 29(3), 226-241. http://dx.doi.org/10.1016/j.jaccpubpol.2010.03.004

Myers, J., Myers, L., \& Omer, T. (2003). Exploring the term of the auditor-client relationship and the quality of earnings: A case for mandatory audit rotation. The Accounting Review, 78(3), 779-799. http://dx.doi.org/10.2308/accr.2003.78.3.779

Navissi, F., Mirza, M., \& Yao, I. (2006). Do stock prices in China reflect information in earnings persistence? Paper presented at the ACESA2006 Conference on "Emerging China: Internal Challenges and Global Implications", Melbourne, AU, July 13-14.

Noronha, C., Zeng, Y., \& Vinten, G. (2008). Earnings management in China: An exploratory study. Managerial Auditing Journal, 23(4), 367-385. http://dx.doi.org/10.1108/02686900810864318

Richardson, S. A., Sloan, R. G., Soliman, M. T., \& Tuna, I. A. (2005). Accrual reliability, earnings persistence and stock prices. Journal of Accounting and Economics, 39(3), 437-485. http://dx.doi.org/10.1016/j.jacceco.2005.04.005

Seligman, S. (1999). Guanxi: Grease for the wheels of China. China Business Review, 26(5), 34-38.

Sloan, R. G. (1996). Do stock prices fully reflect information in accruals and cash flows about future earnings? The Accounting Review, 71(3), 289-315. 
Sutthisit, J., Wu, S., \& Yu, B. (2012). Trading behaviors in Chinese stock markets: Empirical evidence from Shanghai, Shenzhen, and Hong Kong stock exchanges. Journal of Financial and Economic Practice, 12(1), 41-65.

US Congress. (2002). The Sarbanes-Oxley Act of 2002. $107^{\text {th }}$ Congress of the United States of America.H.R. 3763.Government Printing Office, Washington, DC.

Wang, K., \& Wong, T. J. (2003). From government to corporation: largest shareholder's change and firm performance. Unpublished working paper, Tsinghua University and Hong Kong University of Science and Technology. 